\title{
The Challenge of Rail Passenger Service: Free Enterprise, Regulation, and Subsidy
}

\author{
Robert L. Bard
}

Virtually every attempt by an interstate rail carrier to withdraw all or any portion of its services over a given route is potentially subject to the jurisdiction of some federal or state regulatory agency. ${ }^{1}$ Moreover, although a carrier would find it difficult, if not impossible, to achieve total abandonment or discontinuance without proof that the service involved only could be provided at a loss, current national regulatory policy sometimes requires carriers to continue present operations, losses notwithstanding. ${ }^{2}$

On October 11, 1965, the trustees of the New York, New Haven, and Hartford Railroad filed a notice and supporting statement, pursuant to section $13 \mathrm{a}(\mathrm{l})$ of the Interstate Commerce Act, of the railroad's intention to discontinue all of its then existing interstate passenger train operations. ${ }^{3}$ Such action would have affected 273 interstate trains providing suburban services between New Haven and New York City, and Providence and Boston, and through services between Springfield and

Robert L. Bard, Graduate Fellow, The University of Chicago Law School, received an A.B. degree in 1952 and an M.A. in Economics in 1955 from the University of Michigan, and an LL.B. in 1959 from Yale University. The author wishes to express his gratitude to Professor G. Shorey Peterson of the University of Michigan Department of Economics for his valuable suggestions.

1 Withdrawal of all remaining services over a given portion of a railroad's line is usually termed "abandonment" or "total abandonment." Withdrawal of only a portion of the services is usually termed "partial abandonment," "discontinuance," or "partial discontinuance." Alabama Pub. Serv. Comm'n v. Southern Ry., 341 U.S. 341 (1951); Palmer v. Massachusetts, 308 U.S. 79 (1939); Gulf M. \& O.R.R. v. Louisiana Pub. Serv. Comm'n, 120 F. Supp. 250 (D. La. 1954). However, the court's usage of these terms tends to be uneven. See Creston Grain \& Lumber, Inc. v. United States, 214 F. Supp. 840 (D. Neb. 1963) (withdrawal of all remaining services on a branch line termed "partial abandonment"); Sludden v. United States, 211 F. Supp. 150 (M.D. Pa. 1962) (withdrawal of all passenger service termed both "discontinuance" and "abandonment").

In this article "abandonment" refers to any kind of service withdrawal, "total abandonment" to complete withdrawal of all existing services, and "discontinuance" to withdrawal of some but not all existing services.

2 Missouri Pac. Ry. v. Kansas, 216 U.S. 262 (1910).

3 New York, N.H. \& H.R.R. Discontinuance, 327 I.C.C. 151, 152 (1966). 
New York City, and Boston and New York City. During a typical week these trains made 1,244 trips, and during 1964 the railroad carried 75.7 million passengers. According to the Interstate Commerce Commission, in 1964 the New Haven sustained a deficit of $\$ 17$ million, of which $\$ 10.5$ million was attributable to passenger operations. Moreover, the carrier had sustained losses averaging $\$ 11.9$ million in every year commencing with 1957. The Commission attributed these losses to a variety of factors, including financial speculation by the management, poor locomotive policy, inadequate maintenance of plant and equipment, failure to utilize effectively the railroad's full motor carrier operating authority, burdensome state and local taxation, and policies of federal and state governments inequitably promoting competing forms of transportation. ${ }^{4}$

After a short investigation, the Commission temporarily blocked all but a few of the proposed discontinuances. ${ }^{5}$ Given the potential economic, social, and political impact of the action proposed by the carrier on all of southern New England, this result was not a surprising one. Probably it did not even surprise the New Haven trustees. But to sustain its action, the Commission was forced to ignore its own precedents, interpret the controlling legislation extremely liberally, make highly questionable findings of fact, create new substantive standards and procedural devices, and attempt to fashion novel methods of cooperation between railroads and public authorities. The only result of these uncharacteristic heroics was a temporary delay, and the entire process was almost certain to be repeated within less than a year from the decision.

The Commission's agonized response in the New Haven case was the product of the utter inadequacy of the administrative instruments available to it for the resolution of the passenger service problems of a nationwide, privately owned rail transportation system providing the two economically disparate commodities of passenger and freight carriage, intermittently subject to government planning, subsidization, and control, and operating within a complex, changing economy. This article analyzes the economic, political, and legal framework within which questions of the continuance of specified rail services are presented and resolved, and points to the inadequacy of that framework. It also suggests alternative approaches for dealing with railroad abandonment problems.

$4 I d$. at 163-73.

$5 \mathrm{Id}$. at 225. 


\section{Why Rail Passenger Service Causes Problems}

Among the factors that have contributed to the predicament of rail passenger service are the economic characteristics of this service, the structure of American railroads, and the division of responsibility for the regulation and welfare of the national transportation system among a large number of authorities, both federal and state. Therefore, it may be profitable to commence our analysis of the rail passenger problem with some discussion of the economic and political parameters within which the problem must be confronted.

\section{Inherent Economic Peculiarities of Rail Passenger Service}

Rail service, unlike most other goods and services, may become unavailable to particular consumers at any price. To transport one passenger or piece of freight, a railroad must have at least one locomotive, crew, car, railroad bed and track, and control system. Of course, for practically the same cost the carrier could accommodate many times more passengers or pieces of freight. And by attaching a few more cars to the locomotive or by using the same equipment to make more trips, the total carriage could be further increased at minimum additional cost. Given the high costs of locomotives, crews, etc., a substantial amount of traffic is required to enable a carrier to recover its costs for any given run. Thus, if the carrier is to operate solely on a paying basis, a large number of potential customers may be denied all services if the minimum figure cannot be obtained. Rail services present then a situation in which the opportunity of each consumer to buy a product is dependent upon the whims of the consumer's neighbors in a manner not usually encountered in our economic life.

Admittedly, railroads are not unique in demanding a very large input to produce the first unit of product. But the output of most other heavy industries is transportable, a fact that enables them to accumulate sufficient demand on a worldwide basis. Even electric power, which because of the large capital input required to provide efficient service and the expense of duplicating transmission facilities is granted regulated monopoly status, may be transported long distances to remote users. Railroad services, unfortunately, are totally immobile, and carriers are thus limited to the demand generated in the immediate vicinity of their tracks. Other "services," such as skiing in the Alps and enjoying the warmth of Bermuda in February, require more demand to meet fixed costs than is available in their immediate environs and are as immobile as the Long Island Railroad; but purchasers of these "ser- 
vices" can be attracted on a worldwide basis in sufficient numbers to support the costs of the operations. Excepting, perhaps, the San Francisco cable cars and the final trips of defunct passenger trains, rail lines are not tourist attractions and cannot hope to supplement local demand with visitors from afar.

The regulatory problem is further complicated by the interdependence of the various parts of a rail system and the ability of the same equipment to handle both freight and passengers. Rail lines usually cannot be broken into pieces with service along certain segments of continuous lines but no service along others. Thus, the feasibility of service along one portion of a line depends upon the railroad's ability to achieve given earnings along the rest of the line; and although various communities along the total length of the carrier's run may have different interests in preserving the service and may be willing to make different sacrifices to do so, the rail carrier's only choices may be to provide service to everyone or no one. ${ }^{6}$ Finally, although the same equipment may be able to provide freight and passenger services, the political, economic, and social interests related to each type of service are likely to differ substantially. ${ }^{7}$

\section{Private vs. Public Value}

A second important aspect of rail service is that, typically, the value to the public of a given level of service exceeds the amount that will be paid by customers to obtain the service. As rail fares increase or auto travel becomes cheaper or more convenient, more commuters may prefer to use the highways. If so, at some point the carrier may find itself unable to recover the costs of providing the service. But when all the costs connected with the withdrawal of the service and the increased car usage are totalled, it may appear that it would have been cheaper for the economy as a whole for the railroad to have continued the service and the commuter to have left his car at home. ${ }^{8}$

6 Moreover, the system of rate regulation applicable to railroads adds to the problem. Under existing practices, a carrier's ability to maximize revenues by adjusting prices is limited by the requirement that rates must fit within a general pattern in order to avoid economic distortions and discrimination between geographic sectors. Thus, the carrier is often not permitted to adjust the price, if there by any, of certain high-cost services to a level that would permit operation without loss, since this might create discontinuities and discriminations within the pricing system. See III-B Sharfman, The Interstate Commerce Commission 309-768 (1936).

7 For a general discussion of the special features of railroad services, see Froma, TransPORT INVESTMENT AND ECONOMIG DEVELOPMENT (1965); Baumol, The Role of Cost in the Minimum Pricing of Railroad Services, 36 U. CHI. J. Bus. 336-51 (1963).

8 For a general discussion of the relationship between financial and social considerations 
Public costs of withdrawing rail service are of several varieties. One class includes the financial and other damage that may be suffered by persons and industries who have made economic and personal commitments on the assumption that a service would continue to exist. A second class includes the indirect costs engendered by increased use of alternative forms of transportation. A withdrawal of rail service diverts passengers to airplanes, buses, trucks, and private cars. Rail transportation uses, however, far less land space per passenger-mile than does rubber wheeled or airborne transportation. ${ }^{9}$ Moreover, the employment of rubber wheeled transportation brings with it the high costs of combatting congestion and air pollution; ${ }^{10}$ and in many areas, particularly the eastern seaboard, the cost of building additional airports adjacent to already overcrowded metropolitan centers is enormous. ${ }^{11}$

\section{The Political and Administrative Setting of Railroad Regulation}

The inherent economic difficulties of rail service are further complicated by the political and administrative setting within which its problems must be solved. Although railroads are just one of several competing forms of transportation, no national plan exists for allocating traffic between rail, road, water, and air; nor are there any clear guidelines to assist agencies that must make decisions in this area. Moreover, the uncoordinated policies with respect to competing forms of transportation have been ones of sizeable subsidy, which has made it even more difficult for the railroads to compete on a price basis. ${ }^{12}$ And although the Interstate Commerce Commission now effectively regu-

see Lockin, Economics of Transportation 835-37 (5th ed. 1960); III-A Sharfman, The Interstate Commission 332-46 (1935); Nelson, Pricing Transportation Services, in TransPORTATION INVESTMENT \& ECONOMIC DEVELOPMIENT 198, 209 (1965).

- Statement of Sec'y of Commerce John Connor, Hearings Before the Subcommittee on Transportation and Aeronautics of the House Committee on Interstate and Foreign Commerce, 89th Cong., Ist Sess., ser. 89-17, at 148 (1965).

10 One response to this problem was the recent legislation authorizing research and demonstration programs on the possibilities of high-speed interurban rail transportation. 79 Stat. 893 (1965), 49 U.S.C. \& 1631 (Supp. I 1965). For a general discussion of the considerations behind the program see Hearings Before the Subcommittee on Transportation and Aeronautics of the House Committee on Interstate and Foreign Commerce, 89th Cong., Ist Sess., Ser. 89-17 (1965).

11 Washington National Airport is a prime example of overcrowding. As a result the Federal Aviation Agency has acted to curtail the number of flights into and out of National. See N.Y. Times, July 12, 1966, p. 31, col. 3.

12 Fainsod, Gordon \& Palamountain, Governatent and the American Economy 3-416 (3d ed. 1959); Locklin, Economics of Transportation, 823-66 (5th ed. 1960). Section 7 of the act creating the Department of Transportation requires that body to develop criteria for evaluating national investment in transportation. 80 Stat. 941 (1966), 49 U.S.C.A. $\S 1656$ (Supp. 1966). 
lates most surface transportation, it has but limited authority over water carriage and none over air carriage. ${ }^{13}$

\section{Jurisdictional and Procedural Aspects of Abandonment}

As a result of a recent amendment to the Interstate Commerce Act, (the "Act"), all total abandonments and discontinuances by carriers operating in interstate commerce are now subject to at least the concurrent jurisdiction of the Interstate Commerce Commission. ${ }^{14}$ Until quite

13 Authority over interstate motor transportation was ceded to the ICC by the Motor Carrier Act of 1935, 49 Stat. 543 (1935), 49 U.S.C. $\$ \$ 301-27$ (1964).

Although partial ICC jurisdiction over water carriage dates back to the Interstate Commerce Act of 1887, 24 Stat. 379 (1887), prior to 1940 the Maritime Commission regulated common carriers in the coastal trade and on the Great Lakes, and common and contract carriers in the intercoastal trade. 39 Stat. 728 (1916); 47 Stat. 1425 (1933). The Transportation Act of 1940 transferred jurisdiction over these areas to the ICC and added other types of shipping. 54 Stat. 929 (1940), 49 U.S.C. $\$ \S 901-23$ (1964). However, the same act exempted from all regulation private carriers, contract carriers whose equipment and cargoes are so specialized that they do not compete with common carriers, common carriers whose cargoes consist of not more than three commodities transported in bulk, carriers of liquid cargoes in bulk in tank vessels, small craft, and ferries operated incidentally by railroads, motor carriers, or express companies. 54 Stat. 931-33 (1940), 49 U.S.C. $\S \S 903(\mathrm{~b})$-(h) (1964).

Jurisdiction over air transportation is divided between the Federal Aviation Agency and the Civil Aeronautics Board. 72 Stat. 737 (1958); 75 Stat. 467 (1961); 76 Stat. 143 (1962), 49 U.S.C. $\S \S 1301-1542$ (1964). Generally, the Board regulates rates and routes, and the Agency is responsible for promotion and safety. There is a provision for a joint board of the $\mathrm{CAB}$ and ICC to consider matters relating to through service and joint rates, fares, and charges. 72 . Stat. 791 (1958), 49 U.S.C. $§ 1483$ (1964).

1472 Stat. 571 (1958), 49 U.S.C. \& 13a (1964): Discontinuance or change of the operation $\checkmark$ or service of trains or ferries; notice; investigation; hearing; determination.

(1) A carrier or carriers subject to this chapter, if their rights with respect to the discontinuance or change, in whole or in part, of the operation or service of any train or ferry operating from a point in one State to a point in any other State or in the District of Columbia, or from a point in the District of Columbia to a point in any State, are subject to any provision of the constitution or statutes of any State or any regulation or order of (or are the subject of any proceeding pending before) any court or an administrative or regulatory agency of any State, may, but shall not be required to, file with the Commission, and upon such filing shall mail to the Governor of each State in which such train or ferry is operated, and post in every station, depot or other facility served thereby, notice at least thirty days in advance of any such proposed discontinuance or change. The carrier or carriers filing such notice may discontinue or change any such operation or service pursuant to such notice except as otherwise ordered by the Commission pursuant to this paragraph, the laws or constitution of any State, or the decision or order of, or the pendency of any proceeding before, any court or State authority to the contrary notwithstanding. Upon the filing of such notice the Commission shall have authority during said thirty days' notice period, either upon complaint or upon its own initiative without complaint, to enter upon an investigation of the proposed discontinuance or change. Upon the institution of such investigation, the Commission, by orders served upon the carrier or carriers affected thereby at least ten days pior to the day on which such discontinuance or change would otherwise become effective, may require such train or ferry to be con- 
recently, however, important categories of service withdrawals were regulated by the states alone. And in the process of enlarging the Commission's jurisdiction to embrace all abandonments, Congress has created serious procedural difficulties and incongruities: the procedures applicable to discontinuances differ from those applicable to total abandonments, and the procedures applicable to discontinuances of services rendered across at least one state line ("interstate discontinuances") differ from those applicable to discontinuances of services rendered within a single state ("intrastate discontinuances"). Neither of these distinctions can be justified in terms of the nature of the services involved. In addition, the procedures applicable to interstate discontinuances seem unduly to impede the Commission's efforts to

tinued in operation or service, in whole or in part, pending hearing and decision in such investigation, but not for a longer period than four months beyond the date when such discontinuance or change would otherwise have become effective. If, after hearing in such investigation, whether concluded before or after such discontinuance or change has become effective, the Commission finds that the operation or service of such train or ferry is required by public convenience and necessity and will not unduly burden interstate or foreign commerce, the Commission may by order require the continuance or restoration of operation or service of such train or ferry, in whole or in part, for a period not to exceed one year from the date of such order. The provisions of this paragraph shall not supersede the laws of any State or the orders or regulations of any administrative or regulatory body of any State applicable to such discontinuance or change unless notice as in this paragraph provided is filed with the Commission. On the expiration of an order by the Commission after such investigation requiring the continuance or restoration of operation or service, the jurisdiction of any State as to such discontinuance or change shall no longer be superseded unless the procedure provided by this paragraph shall again be invoked by the carrier or carriers.

(2) Where the discontinuance or change, in whole or in part by a carrier or carriers subject to this chapter, of the operation or service of any train or ferry operated wholly within the boundaries of a single State is prohibited by the constitution or statutes of any State or where the State authority having jurisdiction thereof shall have denied an application or petition duly filed with it by said carrier or carriers for authority to discontinue or change, in whole or in part, the operation or service of any such train or ferry or shall not have acted finally on such an application or petition within one hundred and twenty days from the presentation thereof, such carrier or carriers may petition the Commission for authority to effect such discontinuance or change. The Commission may grant such authority only after full hearing and upon findings by it that (a) the present or future public convenience and necessity permit of such discontinuance or change, in whole or in part, of the operation or service of such train or ferry, and (b) the continued operation or service of such train or ferry without discontinuance or change, in whole or in part, will constitute an unjust and undue burden upon the interstate operations of such carrier or carriers or upon interstate commerce. When any petition shall be filed with the Commission under the provisions of this paragraph the Commission shall notify the Governor of the State in which such train or ferry is operated at least thirty days in advance of the hearing provided for in this paragraph, and such hearing shall be held by the Commission in the State in which such train or ferry is operated; and the Commission is authorized to avail itself of the cooperation, services, records and facilities of the authorities in such State in the performance of its functions under this paragraph. 
analyze the factors involved in situations in which carriers are seeking extensive discontinuances of important services.

\section{The Shift from State to Federal Jurisdiction Over Discontinuances}

For more than half a century the inherent inconsistency between the federal government's power to regulate railroads pursuant to the commerce clause and the states' power to exercise similar authority pursuant to their "police" function and to whatever residual functions are left them by the tenth amendment has been resolved in favor of almost complete and exclusive federal (Interstate Commerce Commission) jurisdiction. ${ }^{15}$ But despite manifest constitutional and apparent legislative authority, prior to the 1958 amendment to the Act the Commission had resolved the politically delicate problem of the regulation of railroad abandonments by limiting its own jurisdiction in accordance with the somewhat dubious "partial abandonment" doctrine. ${ }^{16}$ Thus limited, ICG jurisdiction extended only to complete cessations of all operations by a carrier over a given line. The states were ceded exclusive control over partial abandonments or discontinuances; that is, those situations in which a railroad eliminated some but not all operations over the relevant line. ${ }^{17}$ The logic of the resulting jurisdictional pattern was undermined, however, by the fact that although the problems attendant upon the total abandonment of all services on a branch line by a carrier continuing operation in other parts of its system were largely identical with those attendant upon the withdrawal of part of the services on a given line, branch line abandonments were reserved

15 See I Sharfman, The Interstate Commerce Commission 177-82, 239-44, 282-92 (1931). Thus, the courts have ruled that the Commission was constitutionally and legislatively empowered to assert jurisdiction over the abandonment of a railway line wholly located within a single state and physically unconnected with rail lines in any other state but owned by a carrier operating railway lines beyond the state's borders. Colorado v. United States, 27 I U.S. 153 (1926); Illinois v. United States, 213 F. Supp. 83 (N.D. Ill. 1962), aff'd, 373 U.S. 378 (1963).

16 Alabama v. Southern Ry., 341 U.S. 341 (1951); Board of Pub. Util. Comm'n v. United States, 158 F. Supp. 104 (D. N.J. 1957); Gulf M. \& O.R.R. v. Louisiana Pub. Serv. Comm'n, 120 F. Supp. 250 (D. La. 1954).

17 This policy was based on the Commission's reading of section $1(18)$ of the Act. Public Convenience Application of Kansas City So. Ry., 94 I.C.C. 691 (1925). Although the courts have never directly challenged the Commission's limitation of its jurisdiction in this area, neither have they made an independent analysis of the authority and logic of this proposition. The principal judicial support for the partial abandonment doctrine, Palmer v. Massachusetts, 308 U.S. 79 (1939), does no more than cite the Commission's decision in Kansas City So. Ry. Moreover, this restrictive view of abandonment jurisdiction would appear inconsistent with the plenary authority successfully asserted by the Commission over the analagous problems of the regulation of the intrastate freight and passenger rates of interstate carriers. Railroad Comm'n v. Chicago, B. \&. Q.R.R., 257 U.S. 563 (1922); Illinois Cent. R.R. v. Pub. Stat. Util. Comm'n, 245 U.S. 493 (1918); Houston, E. \& W.T. Ry. v. United States, 234 U.S. 342 (1914) (Shreveport case). 
for ICC jurisdiction. ${ }^{18}$ As a result of this complication, a federal strain of discontinuance law grew up alongside state law.

Further debate regarding the wisdom of the partial abandonment doctrine was rendered moot by the changes in the Act effected by section 5 of the Transportation Act of 1958 (the "Transportation Act"). ${ }^{19}$ Under the Transportation Act, interstate rail carriers are empowered to substitute federal jurisdiction, as exercised by the ICC, for state surveillance. Indeed, with regard to some interstate discontinuances a carrier may now implement its plans without benefit of state or federal sanction. In addition, the Transportation Act provides standards designed to guide the Commission in exercising its new jurisdiction, and these standards differ at least in form from those applicable to total abandonments.

\section{Interstate Discontinuances}

Interstate discontinuances are now subject to federal jurisdiction in accordance with section $13 \mathrm{a}$ of the Act. ${ }^{20}$ Under this section, railroads contemplating interstate discontinuances must notify the ICG and the governors of every state in which the train or ferry at issue is operated, and must post notices in every station or depot served by the line, of

18 Gulf, M. \& O.R.R. Abandonment, 290 I.C.C. 701 (1955); New York Cent. R.R. Abandonment, 254 I.C.C. 745 (1944); Morris \& E.R.R. Proposed Abandonment, 175 I.C.C. 49 (1931). ICC jurisdiction also extended to the abandonment of all interstate traffic on a line maintaining intrastate traffic. Maine Cent. R.R. Abandonment, 207 I.C.C. 97 (1935). 1972 Stat. 571 (1958), 49 U.S.C. § 13a(1) (1964). Actually, section 13a implicitly recognizes residual state power over discontinuances. Section $13 \mathrm{a}(\mathrm{I})$ applies to carriers whose "rights with respect to ... discontinuance . . . are subject to any provision of the constitution or statutes of any State or any regulation or order of ... any court or an administrative or regulatory agency of any State. .. ." Section 13a(2) applies "where the discontinuance is prohibited by the constitution or statutes of any State or where the State authority having jurisdiction thereof shall have denied an application or petition ... for authority to discontinue . . . Thus, rather than rejecting the partial abandonment doctrine, Congress seems to be recognizing state jurisdiction over certain withdrawals of rail services, presumably those withdrawals encompassed by the partial abandonment doctrine. From this it should follow that absent state jurisdiction the carrier would be free of all regulation.

20 As an alternative basis for its decision, a three judge court has asserted that a carrier may invoke section 13a(1) in cases subject to Commission jurisdiction under section 1(18). Minnesota v. United States, 238 F. Supp. 107 (D. Minn. 1965). This position seems dubious since jurisdiction under section $13 \mathrm{a}$ is limited to situations in which a carrier's rights with respect to discontinuance are subject to state jurisdiction, and a state has no jurisdiction over total abandonments within the ambit of section 1(18). See Thompson v. Texas M. Ry., 328 U.S. 134 (1946).

Section $13 \mathrm{a}(\mathrm{l})$ applies to interstate trains also rendering intrastate service. Sludden v. United States, 211 F. Supp. 150 (M.D. Pa. 1962). And in one case the Commission appeared to apply section $13 a(1)$ to trains crossing state borders which render passenger service solely within one of the states. See New York, N.H. \& H.R.R., 327 I.C.C. 151, 200 (1966). 
the intended changes at least thirty days prior to the effective date thereof. ${ }^{21}$ Then, unless within the thirty day period the ICC (either upon complaint or its own motion) determines that an investigation is necessary, the carrier is free to proceed with the discontinuance. ${ }^{22}$ If an investigation is ordered, the ICG may delay the discontinuance up to four months pending a hearing and decision. ${ }^{23}$ Thereafter, if the Commission determines that the services in question are required by public convenience and necessity and that their maintenance will not unduly burden interstate commerce, the carrier may be ordered to continue all or some of the services for a period of up to one year from the date of the Commission's order. Upon the expiration of this period, the carrier would again be free to file for discontinuance with the appropriate state authorities or to resort again to the mechanism outlined in this paragraph.

The propriety of empowering rail carriers to discontinue services on interstate lines without mandatory hearings before any regulatory or judicial body, state or federal, has been upheld by the courts against attacks on statutory and constitutional grounds. ${ }^{24}$ Admittedly the ability of carriers to discontinue under section 13a(1) without prior approval from any regulatory authority represents a departure from past practice. ${ }^{25}$ But the cases hold that Congress intended to give the

21 The notice required by the Act does not include publication in the Federal Register. Chicago \& N.W. Ry. Discontinuance, 307 I.C.C. 463 (1959).

22 The Commission has no power to delay a section $13 a(1)$ proceeding to await the outcome of state proceedings that might eliminate all remaining service on the line in question. Louisville \& N.R.R. Discontinuance, 307 I.C.C. 173, 175 (1959). And a contractual obligation by the carrier to continue service does not bar ICC jurisdiction under 13a(1), New York, N.H. \& H.R.R. Discontinuance, 327 I.G.C. I51, 199 (1966), although the carrier would be subject to suit if it violated its contractual obligations.

23 All parties may participate in $13 \mathrm{a}(\mathrm{l})$ proceedings without offering a formal pleading or proving that they have a specific interest in the outcome. Minneapolis \& St. L. Ry. Discontinuance, 307 I.C.C. 79 (1959).

24 In New Jersey v. United States, 168 F. Supp. 324 (D.N.J. 1959), aff'd per curiam, 359 U.S. 27 (1959), it was claimed that sections 13(1) and (2), which compel the Commission to investigate colorable allegations of a carrier's violations of the Act, apply to discontinuances under section 13a(1); that Congress exceeded its powers under the commerce clause in assuming jurisdiction over partial discontinuances; and that failure to hold a hearing in such circumstances would violate the fifth amendment by depriving the carrier's patrons of property without due process. The court held that the juxtaposition of section 13a with sections 13(1) and (2) was fortuitous; and that since Congress could occupy the entire field of interstate transportation, it had authority to divide its jurisdiction between the states and the ICC as it deemed fit, or to withhold jurisdiction from both.

25 Prior Commission approval is required for branch line abandonments under sections $1(18)$ and (20) of the Act, and under the partial abandonment doctrine state law invariably required similar approval. However, it has been held that once Congress has chosen to exercise federal jurisdiction it is free to give the ICC such authority as it chooses, or if Congress so wishes it may insulate an interstate carrier from the jurisdiction of all regulatory bodies, state or federal. New Jersey v. United States, I68 F. Supp. 324, 331-32 
Commission full discretion regarding the necessity for investigations and hearings in section $13 \mathrm{a}(1)$ interstate discontinuance cases, ${ }^{26}$ and that giving such discretion does not constitute a deprivation of property cognizable by the fifth amendment. ${ }^{27}$ Indeed, the federal courts have held themselves to be without jurisdiction to review ICG decisions permitting, or terminating investigations of, $13 \mathrm{a}(1)$ discontinuances. This has been based on the ground that the Commission's power not to conduct any investigations at all necessarily implies the lesser power at issue. ${ }^{28}$

\section{Intrastate Discontinuances}

Withdrawals of portions of interstate carriers' services on lines wholly located within a single state are covered by section 13a(2) of the Act. ${ }^{29}$ Although the procedures specified in that section are more burdensome to carriers than the interstate discontinuance procedures specified in section $13 \mathrm{a}(1)$, the former do permit a carrier to opt for ICC jurisdiction if it fails to obtain state sanction for a proposed change of service. ${ }^{30}$ To trigger ICC jurisdiction, either the carrier must have been prohibited from implementing its discontinuance by state constitutional, statutory, or regulatory authority; or an appropriate state authority presented with a request for such discontinuance must

(D.N.J. 1959). In this regard, if the Commission fails to order an investigation within the thirty day period provided by the statute, it loses all jurisdiction over the matter. Sludden v. United States, 211 F. Supp. 150, 154 (M.D. Pa. 1962).

26 Pennsylvania R.R. v. Sharfsin, 240 F. Supp. 233 (M.D. Pa. 1965).

27 Unlike rate or tariff changes, partial discontinuances relate to the general federal power to regulate commerce which overrides any individual rights in a railroad's operations. Under these circumstances the court believed that the only way to compel the ICC to hold a hearing on a proposed discontinuance under section 13a(1) was by petitioning for a writ of mandamus in the Court of Appeals for the District of Columbia, alleging abuse of discretion. New Jersey v. United States, 168 F. Supp. 324, 334 (D.N.J. 1959).

28 New Hampshire v. Boston \& M. Corp., 251 F. Supp. 421 (D.N.H. 1965); Minnesota v. United States, 238 F. Supp. 107 (D. Minn. 1965). However, in at least two cases, three judge courts have affirmed, per curiam and without opinion, ICC determinations not to instigate investigations under 13a(1). Rhodes v. United States, Civ. A. No. 63-477 (M.D. Pa. 1963); California v. United States, Civ. A. No. 38915 (N.D. Cal. 1961). Although these affirmances may be interpreted as implicitly supporting the reviewability of this type of ICC determination, they more likely stem from a failure to observe the procedural nicety of dismissing the appeal for lack of jurisdiction. Although the statute clearly demands non-reviewability of decisions not to start or continue an investigation, once the process culminates in an opinion and order the general presumption in favor of reviewability becomes somewhat stronger.

2972 Stat. 572 (1958), 49 U.S.C. § 13a(2) (1964); see note 14 supra.

30 Discontinuance of all remaining intrastate passenger service is subject to section 13a(2) procedures. Boston \& M. Corp. Discontinuance, 324 I.C.C. 705, 706-07 (1965). Moreover, once the ICC acquires jurisdiction, it is not lost by subsequent state action even if such action might render moot the 13a proceedings. Northern Pac. Ry. Discontinuance, 312 I.C.C. 150, 156 (1960). 
have failed to take final action on such request within 120 days of its presentation. ${ }^{31}$ There is no requirement that the carrier must exhaust its state judicial remedies, and the decisions and findings of the state authorities have no res judicata or collateral estoppel effect. ${ }^{32}$ Once its jurisdiction has been established, and it has held a full hearing in the affected state, the ICC may sanction the discontinuance if it finds that the present or future public convenience and necessity permit and that continued operations on the existing basis will constitute an unjust and undue burden on the interstate operations of the carrier or on interstate commerce. Unlike decisions barring proposed interstate discontinuances, which are effective for only one year, ICG refusals to permit intrastate discontinuances under section $13 \mathrm{a}(2)$ are temporally unlimited. ${ }^{33}$

\section{High Hurdles and Low Hurdles}

The three types of abandonment are thus subject to increasingly difficult procedural requirements. Interstate discontinuances are the most favored, since the carrier may initiate them without prior Commission approval (albeit subject to a Commission-ordered stay). Total abandonments come next, since the carrier may petition the ICG directly. Intrastate discontinuances are the least favored, since they require prior nonaction or negative action by an appropriate state regulatory agency. ${ }^{34}$ The discrepancies between interstate and intrastate

31 In one case the state unsuccessfully attempted to avoid ICC jurisdiction by alleging that the state authority to which the carrier originally had submitted its request for discontinuance did not have jurisdiction over the matter. Although the Commission failed to explain its decision, the state authority apparently did not assert lack of jurisdiction at the time of the original petition, and perhaps this rendered the bona fides of the argument somewhat suspect. See Boston \& M. Corp. Discontinuance, 324 I.C.C. 705, 708 (1965).

32 North Carolina v. United States, 210 F. Supp. 675 (M.D.N.C. 1962).

33 The statute requires continued operation unless the Commission can be induced to grant authority to discontinue. 72 Stat. 572 (1958), 49 U.S.C. $\S 13 a(2)$ (1964). Apparently there is no limit on the number of times the carrier may petition the Commission for authority to discontinue, but must again go through state procedures as a prerequisite to further access to the ICC.

34 Quite naturally, carriers attempt to bring themselves within section $13 \mathrm{a}(1)$ whenever possible, rather than subject themselves to the more rigorous procedures of section $13 \mathrm{a}(2)$. These efforts have met with mixed success. New Jersey v. New York S. \& W.R.R., 372 U.S. 1 (1963), reversing 200 F. Supp. 860 (D.N.J. 1961) (line wholly within N.J. with leased bus service to N.Y. deemed intrastate and subject to section $13 \mathrm{a}(2)$; Texas \& P. Ry. Discontinuance, 307 I.G.C. 259 (1959) (trains operating to Texas-Arkansas border with part of train crossing border and terminal in both states deemed interstate discontinuance subject to $13 a(1))$.

In addition to arguing for section 13a(2) jurisdiction, at least one state, in order to assure hearings in proposed interstate discontinuance cases, has challenged the partial 
discontinuances resulted from an uneasy compromise between the original Senate bill, which would have applied the more liberal requirements to all discontinuances, and the original House version, which would have ceded complete jurisdiction over intrastate discontinuances to the states. ${ }^{35}$

With all discontinuances now subject to federal jurisdiction, separate procedures for interstate and intrastate discontinuances are difficult to justify. Possibly, exclusive state jurisdiction over interstate discontinuances might be deemed a greater burden to carriers than similar jurisdiction limited to intrastate discontinuances, on the ground that the former would subject carriers to two or more possibly conflicting state authorities. But having established ICC jurisdiction over both types of discontinuances, the legislation should have provided similar procedural requirements. That a rail service to be discontinued crosses a state boundary does not alter the service's importance to the residents of the affected states. And where a proposed discontinuance involves both interstate and intrastate services, and the two cannot be economically disentangled, the necessity for separate procedures unduly complicates the Commission's efforts to view the issues in proper perspective, particularly in view of the short time limitations imposed by section 13a(1). ${ }^{36}$ In the New Haven Railroad case this difficulty apparently induced the Commission to ignore the statute and to include proposed intrastate discontinuances in a $13 \mathrm{a}(1)$ proceeding. ${ }^{37}$

Moreover, both the interstate and intrastate procedures specified by the Act have dubious aspects. Requiring consideration of intrastate discontinuances by state authorities as well as the ICC serves only to

abandonment doctrine originally created for its benefit by attempting to establish ICC jurisdiction under section 1 (18) rather than section 13a(1). Minnesota v. United States, 238 F. Supp. 107 (D. Minn. 1965).

35 S. REP. No. 1647, 85th Cong., 2d Sess. 31-32 (1958). H.R. Rep. No. 1922, 85th Cong., 2d Sess. 47-48 (1958). The entire Transportation Act is characterized by largely unsatisfactory compromises between the more carrier and federal minded Senate and the more commuter and state oriented House. The measure was passed on August 12, 1958, only twelve days prior to adjournment of the 85th Congress, and changes in ICC jurisdiction over intrastate abandonments were made on the floor of Congress, 104 Cong. REc. 10862,10864 (1958). As a result, the new legislation presents a crazy quilt of illogical distinctions, a host of new terms undefined and largely undefinable, and the absence of any clear legislative history in certain aspects of the bill. Some measure of the resulting confusion may be seen in a recent Supreme Court case pertaining to a section 13a(2) discontinuance in which both the majority and the dissent cite the same legislative history to support opposite conclusions. Southern Ry. v. North Carolina, 376 U.S. 93, 101-03 (1964) (majority); id. at 114-18 (dissent).

30 See Boston \& M. Corp. Discontinuance, 324 I.C.C. 418, 424 (1965).

37 New York, N.H. \& H.R.R., 327 I.C.C. 151, 199-201 (1966). Some commissioners found fault with this procedure. $I d$. at 226,229 (concurring opinion). 
delay final outcomes and to burden carriers with increased litigation costs, especially since neither state decisions nor findings of fact bind the ICC. At the same time, a system in which carriers can always obtain a de novo ICC hearing after state authorities have failed to grant a partial discontinuance may tempt state authorities to sidestep their duty to grant justified but politically unpopular discontinuances.

The procedures applicable to interstate discontinuances subject the Commission to unfair and unnecessary pressure. After the filing of the required notices by the carrier, the Commission has only four months to investigate the matter and make a decision. ${ }^{38}$ In the case of extensive and highly complex discontinuances, such as those proposed by the New Haven and the Boston \& Maine railroads, the Commission has been forced to shortcut its usual procedures and has complained of the lack of time for an adequate analysis, decision, and opinion. ${ }^{39}$ Also with respect to interstate discontinuances, the Commission may only order a stay for a maximum of one year, after which time the carrier may renew its petition. In order to extend a stay, the Commission must embark upon another investigation and make new findings. ${ }^{40}$

Finally, no sound basis exists for providing different procedures for total abandonments and discontinuances. The two forms of service withdrawal are virtually indistinguishable in terms of their respective impacts upon the existing consumers of the services to be withdrawn. If a carrier discontinues either freight or passenger service without discontinuing the other, this is considered a partial discontinuance..$^{41}$ If a carrier discontinues either freight or passenger service after having previously discontinued the other, however, this is considered a total abandonment. ${ }^{42}$ Clearly, the effect on the customers losing the discontinued service is the same in both cases. By the same token, although discontinuances of both passenger and freight services certainly have greater financial effects on the carrier and affect greater numbers of persons than do discontinuances of just one service, the users of freight and passenger services rarely are the same persons. In other words, the loss of freight as well as passenger service generally will not complicate the commuter's problems, and vice versa.

3872 Stat. 571 (1958), 49 U.S.C. § 13a(1) (1964); see note 15 supra.

39 New York, N.H. \& H.R.R. Discontinuance, 327 I.C.C. 151, 153 (1966); Boston \& M. Corp. Discontinuance, 324 I.C.C. $418,419,421$ (1965).

4072 Stat. 571 (1958), 49 U.S.C. \& 13a(1) (1964).

41 Palmer v. Massachusetts, 308 U.S. 79 (1939); Board of Pub. Util. Comm'rs v. United States, 158 F. Supp. 98, 104 (D.N.J. 1957); Chicago, B. \& Q.R.R. Abandonment, 271 I.C.C. 63 (1948); Morris \& E.R.R. Proposed Abandonment, 175 I.C.C. 49 (1931); Public Convenience Application of Kansas City So. Ry., 94 I.C.C. 691 (1925).

42 United States Feldspar Corp. v. United States, 38 F.2d 91 (N.D.N.Y. 1930); New York Cent. R.R. Abandonment, 254 I.C.C. 745 (1944). 


\section{SUbSTANTIVE Standards}

The ICG's newly acquired jurisdiction over discontinuances must be exercised in accordance with the substantive standards set forth in section 13a of the Act. ${ }^{43}$ Somewhat surprisingly, the standards applicable to interstate and intrastate discontinuances differ, at least in form, both from each other and from the standard applicable to total abandonments set forth in section $1(18)$ of the Act. But the draftsmanship of this portion of the Transportation Act leaves much to be desired, and the intended direction and degree of divergence are left most unclear. Unfortunately, neither the Commission nor the courts have provided much explicit clarification.

\section{Substantive Standards Imposed by Section $13 a$}

Section $13 a(1)$ of the Transportation Act provides that when the ICC exercises its discretion to order an investigation of a proposed interstate discontinuance, it may order the continuance or restoration of all or a part of the service or operation concerned for up to one year upon findings that such service is required by public convenience and necessity, and that its provision will not unduly burden interstate commerce. By contrast, section 13a(2) provides that the ICC may grant intrastate discontinuances only after full hearings and upon findings that the present or future public convenience and necessity permit of such discontinuance or change, and that continued operation or service on the existing basis will constitute an unjust and undue burden upon the interstate operations of the carrier or upon interstate commerce.

\section{The Formal Structure of Section $13 a$}

The formal structure of the substantive portions of section 13a exhibits certain interesting features. Whereas section $1(18)$ posits a single criterion-public convenience and necessity-section 13a seems to posit three or perhaps four separate criteria: public convenience and necessity, undue burden on interstate commerce, unjust burden on interstate commerce, and perhaps burden on interstate operations. Furthermore, with respect to interstate discontinuances the statute apparently places the burden of making the findings necessary to stop the carrier on the Commission, while with respect to intrastate discontinuances the carrier apparently must induce the Commission to find certain things in order to permit the discontinuance. Finally, interstate discontinuances may be prevented only if the Commission makes two findings-that the service is required by public convenience and necessity and that con-

43 See note 14 supra. 
tinued service will not unduly burden the carrier's interstate operations or interstate commerce-while intrastate discontinuances may be prevented if the Commission finds either of these two things.

On its face, section 13a might reasonably be interpreted as establishing undue and unjust burden upon a carrier's interstate operations or upon interstate commerce as something separate and distinct from public convenience and necessity. Under such a division and in accordance with generally accepted terminology, public convenience and necessity would refer to the public need for the service; while undue burden would refer to the impact on the carrier's finances, and ultimately on the rail system, of the losses attributable to the particular service at issue. ${ }^{44} \mathrm{But}$, as will appear, such an interpretation would both represent a sharp departure from previous abandonment law, and have very far reaching consequences for the future of passenger rail service. Therefore, an intensive effort to find the proper interpretation of this language is warranted. Such an effort should include close examination of the wording of the statute itself, of other relevant legislation, of the intent underlying the development of the language through its passage into law, of the consequences of alternate interpretations, and of the decisions of the Commission and the courts.

\section{Standards Applicable to Discontinuances Prior to the Transportation Act}

As previously stated, prior to the Transportation Act the field of abandonment was divided between the ICC and the states, with the former exercising jurisdiction over total abandonments, and the latter exercising jurisdiction over discontinuances under the umbrella of the partial abandonment doctrine. ${ }^{45}$ Abandonments of branch lines, however, were deemed total abandonments for purposes of ICC jurisdiction; ${ }^{46}$ and since the effects of abandonments of branch lines on both consumers and carriers are identical to those of discontinuances, the interpretation of public convenience and necessity in cases of branch line abandonments is relevant here.

The statutory standard for branch line abandonments was and is that no carrier may abandon all or any part of a railroad line without first obtaining a certification from the ICG that the present or future public convenience and necessity permit the abandonment. ${ }^{47}$ Broadly

44 See Southern Ry. v. North Carolina, 376 U.S. 93 (1964); III-A Sharfaran, The INTERSTATE COMMERce CoMmission 331-48 (1935).

45 See text at notes $16-17$ supra.

46 See note 18 supra..

4741 Stat. 477,478 (1920), 49 U.S.C. § 1(18), (20) (1964). 
speaking, this language has been interpreted as requiring the Commission to balance the damage to the railroad which might result from continuance of the service in question against the hardship and inconvenience to interested parties which might result from abandonment. ${ }^{48}$ Railroad workers likely to lose their jobs if abandonments is permitted have been included among the groups whose interests are to be protected. ${ }^{40}$ The Commission has consistently refused, however, to assign predetermined weights to each factor that must be considered, and the cases do not easily yield general rules. For example, although a carrier earning little or no net profits was denied permission to abandon a highly unprofitable branch, ${ }^{50}$ a highly profitable carrier was permitted to abandon a branch sustaining but negligible losses. ${ }^{51}$

Under the partial abandonment doctrine, the states were free to impose any standards they chose within the limits of the due process clause. Here the courts have generally interpreted due process to mean that although carriers (and certain other businesses deemed charged with particular public interest) cannot unilaterally withdraw a portion of their services from the public, ${ }^{52}$ neither can public authorities compel carriers to continue operations despite continuing net losses in their entire enterprise. ${ }^{53}$ Accordingly, the rule has been that a railroad may be required to continue losing operations in a portion of its system so long as its entire system shows profits, or at least operates without a loss. ${ }^{54}$

48 I Sharfman, The Interstate Commerce Commission 177-82, 239-41, 282-92 (1931); III-A Sharfman, supra, at 340 (1935).

49 The Act requires the ICC to condition its approval of any transaction involving a carrier subject to the Act on provision of fair and equitable arrangements to insure that for a period of four years after the effective date of the order the railroad employees will be in no worse position than they were prior to the transaction. 54 Stat. 906-07 (1949), 49 U.S.C. $\S 5(2) f(1964)$. At first, the ICC interpreted this language as applicable only to consolidations, but the Supreme Court deemed it applicable to abandonments as well. ICC v. Railway Labor Executives Ass'n, 315 U.S. 373 (1942). However, protection only must be given in branch line abandonments, since the statute does not apply to total abandonments. Texas Elec. Ry. Abandonment, 257 I.C.C. 700 (1948); Susquehanna \& N.Y.R.R. Abandonment, 252 I.C.C. 81 (1942).

50 Abandonment of Branches by Boston \& M.R.R., I05 I.C.C. 13 (1925).

51 New York Cent. R.R. Abandonment, 282 I.C.C. 283 (1952).

52 Chas. Wolff Packing Co. v. Court of Industrial Relations, 262 U.S. 522 (1923); Munn v. Illinois, 94 U.S. 113, 126 (1876).

53 Brooks-Scanlon Co. v. Railroad Comm'n, 251 U.S. 396 (1920).

54 Railroad Comm'n v. Eastern Tex. R.R., 264 U.S. 79 (1924); Chas. Wolff Packing Co. v. Court of Industrial Relations, 262 U.S. 522, 543 (1923); Bullock v. Florida ex rel. Railroad Comm'n, 254 U.S. 513 (1921); Northwestern Pac. R.R. v. United States, 228 F. Supp. 690, 694 (N.D. Cal. 1964).

However, this rule has been challenged by some courts. United States Feldspar Corp. v. United States, 38 F.2d 91 (N.D.N.Y. 1930); Delaware, L. \& W.R.R. v. Van Santwood, 


\section{Purpose of the Transportation Act}

Legislative history clearly establishes that the Transportation Act stemmed from considerable congressional apprehension regarding the effect of mounting passenger deficits on the solvency of the national rail system, and that the new legislation was intended to facilitate discontinuance of money-losing passenger services. ${ }^{55}$ Indeed, the original Senate bill would have permitted discontinuances solely upon proof that the service could not be provided without a loss. This feature, along with others, fell victim to a complex series of changes resulting from compromises between carrier and passenger interests. ${ }^{56}$ But concern with the harmful effects of continued passenger deficits was generally shared. ${ }^{57}$

\section{Discontinuances and Rate Discrimination}

A further clue to the statute's intent may be derived from noting that the new provisions are located after section 13(4), rather than after

216 Fed. 252 (N.D.N.Y. 1914), 232 Fed. 978 (N.D.N.Y. 1916); Great No. Ry. v. Nagle, 16 F. Supp. 532 (D. Mont. 1936). Isolated cases have conditioned the obligation of a carrier to continue money-losing services upon a demonstration that this would be a "reasonable" requirement in light of the purposes of the regulation. Public Serv. Comm'n v. United States, 56 F. Supp. 351 (S.D.N.Y.), aff'd, 323 U.S. 675 (1944); Northern Pac. Ry. v. Board of R.R. Comm'rs, 46 F. Supp. 340 (D. Mont. 1942). In this regard, a three-judge court in the Fifth Circuit has ruled that requiring a carrier to furnish services of facilities no longer reasonably necessary to serve the public is tantamount to taking its property without due process. Atlantic Coast Line R.R. v. Florida R.R. \& Pub. Util. Comm'n, 96 F. Supp. 583 (N.D. Fla. 1951). See also Southern Ry. v. Alabama Pub. Serv. Comm'n, 91 F. Supp. 980 (M.D. Ala. 1950); Ann Arbor R.R. v. Michigan Pub. Serv. Comm'n, 91 F. Supp. 668 (E.D. Mich. 1950); Atlantic Coast Line R.R. v. Public Serv. Comm'n, 77 F. Supp. 675, 684 (E.D.S.C. 1948).

55 Congressional concern with the problem of surface transportation dates back to 1956. See Hearings of the Subcommittee on Transportation and Communications of the House Committee on Interstate and Foreign Commerce, 84th Cong., 1st Sess. (1956). The overall passenger deficit for the nation's railroads was estimated to be running at $\$ 700$ million annually in 1958. S. REP. No. 1647, 85th Cong., 2d Sess. (1958); H.R. REP. No. 1922, 85th Cong., 2d Sess. (1958).

56 Under the bill first passed by the Senate both interstate and intrastate discontinuances would have been denied if the Commission had found that "the operation or service of such train [is] required by public convenience and necessity and that such operation or service will not result in a net loss therefrom to the carrier or carriers and will not otherwise unduly burden interstate or foreign commerce. . . " S. 3778, 85th Cong., 2d Sess. 6 (1958). Thereafter the Senate bill was amended on the floor to limit ICC jurisdiction to interstate discontinuances. 104 Cong. REc. 10862, 10864 (1958). This would have brought the Senate bill into conformity in this regard with the bill passed by the House. H.R. 12832, 85th Cong., 2d Sess. 10 (1958). The final bill reinstated the ICC's authority over intrastate abandonments but deleted the language that would permit discontinuances solely on the basis of a net loss to the carrier in providing a given service.

57 S. REP. No. 1647, 85th Cong., 2d Sess. (1958); H.R. REP. No. 1922, 85th Cong., 2d Sess. (1958). 
section $1(18)$, the portion of the Act dealing with total abandonments. Broadly speaking, section 13(4) is concerned with state imposed intrastate freight and passenger rates that discriminate against interstate commerce by failing to cover an appropriate measure of the cost of the intrastate service. ${ }^{58}$ Previously, such rates could be challenged by the Commission only if they were found to constitute "undue, unreasonable or unjust discrimination against interstate commerce." 59 To ease the burden of carriers seeking intrastate rate increases under these circumstances, section 13(4) was amended by the Transportation Act to empower the Commission to adjust intrastate rates if they were found to constitute an "undue burden on interstate commerce."60 According to the legislative history, the addition of the same concept of "undue burden" to section 13a was intended to achieve with respect to discontinuances an effect similar to that contemplated by section 13(4) with respect to intrastate rates; namely, to ensure that the ICC would be able to give due emphasis to the impact of money-losing operations on the national transportation system. ${ }^{61}$ Thus, it can be argued that, in the same way it can raise intrastate rates in order to remove burdens from interstate commerce, the Commission can eliminate losing operations threatening a carrier's financial integrity to remove burdens on interstate commerce.

\section{The Most Obvious Interpretation of the Statute}

Under the most obvious interpretation of the statute, different substantive requirements apply to each of the three different types of service

58 Railroad Comm'n v. Chicago, B. \& Q.R.R., 257 U.S. 563 (1922).

50 41 Stat. 484 (1920).

6072 Stat. 571 (1958), 49 U.S.C. $\S 13(4)$ (1964).

61 To this effect, the report of the Senate Committee on Interstate and Foreign Commerce stated that the bill would give the ICC jurisdiction in the field of discontinuances similar to that which it had over intrastate rates under section 13 of the Act so that it might deal with those matters that impose an undue burden on interstate commerce. S. REP. No. 1647, 85th Cong., 2d Sess. 22 (1958). The provision regarding an "unjust burden" on a carrier's operations or upon interstate commerce, though not part of the bill reported out by the Senate Committee, undoubtedly was also inspired by similar language in section 13 with respect to intrastate rates. See $7 \%$ Stat. 571 (1958), 49 U.S.C. $\S 13$ (4) (1964). But the legislative history does not provide a clear indication of the meaning of the term in the context of discontinuances.

The meaning, if any, of "unjust discrimination" was an issue in the first Supreme Court case interpreting the substantive provisions of section 13a. See text at notes 73-81 infra. The Supreme Court has affirmed a lower court decision holding that the addition of the terms "undue burden on interstate commerce" to section 13(4) of the Act added nothing that was not already included in the terms "undue, unreasonable, or unjust discrimination against interstate commerce." Utah Citizens Rate Ass'n v. United States, 365 U.S. 649, affirming 192 F. Supp. 12 (D. Utah 1961). To the extent analogies to section 13 (4) apply to section 13a, this might be interpreted to mean that "unjust" burden is identical to "undue" burden. 
withdrawals-interstate discontinuances, intrastate discontinuances, and total abandonments. Before pursuing this point, however, we must first mention a word about terminology. From the cases to date it seems clear that "unjust burden" is synonymous with "undue burden," and that "undue burden on a carrier's operations" is synonymous with "undue burden on interstate commerce." 62 Thus, only public convenience and necessity and undue burden on interstate commerce remain as identifiably separate criteria. According to our previous analysis, public convenience and necessity refers to the community requirement for the particular service, and undue burden refers to the impact of the losses engendered by the service on the carrier's solvency. With respect to total abandonments under section $1(18)$ we may assume that public convenience and necessity encompasses both these factors.

To illustrate the varying substantive standards applicable to each type of abandonment, we may analyze the statutory requirements in terms of their applicability to various combinations of factors. For convenience, we shall abbreviate public convenience and necessity as "P" and undue burden on interstate commerce as " $U$," and indicate the presence or absence of the particular factor by 1 or 0 . Thus, $\mathrm{P}_{1} \mathrm{U}_{1}$ indicates the presence of both public convenience and undue burden on interstate commerce. These factors can be combined in four ways: $\mathrm{P}_{0} \mathrm{U}_{0}, \mathrm{P}_{1} \mathrm{U}_{0}, \mathrm{P}_{0} \mathrm{U}_{1}, \mathrm{P}_{1} \mathrm{U}_{1}{ }^{63}$

According to section $13 \mathrm{a}(1)$, a carrier must be permitted to discontinue an interstate service unless the Commission finds that the service is required by public convenience and necessity, and that provision of the service will not result in an undue burden on interstate commerce. Or, to use our shorthand, a carrier must continue if the Commission finds $P_{1} U_{0}$; it need not continue if the Commission finds any of the other three possible combinations. Section 13a(2), on the other hand, provides that a carrier may discontinue only if the Commission finds that continued service is not required by public convenience and necessity, and that continued provision of the service would result in an undue burden-that is, $P_{0} U_{1}$. Thus, a carrier must continue if the Commission finds $P_{0} U_{0}, P_{1} U_{0}$, or $P_{1} U_{1}$. Finally, under the balancing

62 See Southern Ry. v. North Carolina, 376 U.S. 93 (1964), and the discussion of "unjust burden" in note 61 supra. The allegation that these concepts are identical is based simply on the failure of the cases to recognize any distinctions between them. See also New York, N.H. \& H.R.R. Discontinuance, 327 I.G.C. 151 (1966); Boston \& M. Corp. Discontinuance, 324 I.C.C. 705 (1965).

63 Apparently the fact that an interstate discontinuance will take effect unless the Commission makes the findings specified by section $13 \mathrm{a}(\mathrm{l})$ does not shift the burden of proof in such cases to the Commission. See Great No. Ry. Discontinuance, 307 I.C.C. 59 (1959). 
test of section 1(18), which weighs public need against burden on the carrier, a carrier must continue if the Commission finds $\mathrm{P}_{1} \mathrm{U}_{0}$; it may abandon if the Commission finds $\mathrm{P}_{0} \mathrm{U}_{1}$; and the outcome is uncertain in the cases of $\mathrm{P}_{0} \mathrm{U}_{0}$ and $\mathrm{P}_{1} \mathrm{U}_{1}$.

Thus, under this approach to the statute, an interstate discontinuance would always be permissible if an undue burden was demonstrated, no matter what the need; and an intrastate discontinuance would never be permissible so long as any need was demonstrated, no matter what the burden; and the success of a petition for total abandonment could not be readily predicted if the facts indicated either great need and great burden, or low need and low burden. Assuming that the number of combinations of $P$ and $U$ yielding abandonment is an adequate measure of the ease of abandonment, we would find, as we did with respect to procedural matters, that interstate discontinuance would rank as the easiest, total abandonment as the next easiest, and intrastate discontinuance as the most difficult.

Upon the basis of the language itself, of the position of section 13a in the Act, of the general congressional purpose, and of the direction of the compromises underlying the legislation, it may be effectively argued that the foregoing represents the "best" interpretation of the relevant statutes. But strict adherence to this interpretation would probably not have yielded the incontrovertibly sensible result reached in the New Haven Discontinuance case, described at the beginning of this article; and it might well force undesirable consequences in such future cases. Close examination of the decisions interpreting section 13a may permit, however, a somewhat more subtle reading of the statute, which may in turn provide a more workable scheme than seemed possible upon first blush.

Is there a Single Substantive Standard for Interstate Discontinuances, Intrastate Discontinuances, and Total Abandonments?

From the cases it seems quite clear that, despite the undeniable difference in language between sections $13 \mathrm{a}(1)$ and (2), and despite the legislative history indicating a congressional intention to make interstate discontinuances less arduous than intrastate discontinuances, both the Commission and the courts treat all discontinuances alike. The refusal of the Commission to assume the burden of proof in interstate discontinuance cases has already been noted. ${ }^{64}$ What has not already been noted is that in every section $13 \mathrm{a}(1)$ interstate discontinuance case in which the Commission has ordered an investigation but decided 
not to block the discontinuance, as well as in every section 13a(2) intrastate discontinuance case, the Commission has made explicit findings that the service was not required by public convenience and necessity, and that continued operations would result in an undue burden on interstate commerce. ${ }^{65}$ As we have seen, these are exactly the findings required by the statute to support an intrastate discontinuance under section $13 \mathrm{a}(2)$, but they are not the ones required to support an interstate discontinuance under section $13 \mathrm{a}(1)$.

Moreover, the Commission in all cases decided under sections $13 a(1)$ and (2) finds either convenience and necessity plus no undue burden, or lack of convenience and necessity plus an undue burden; ${ }^{66}$ it never finds public convenience and necessity plus an undue burden. Since any difference in the standards for evaluating interstate and intrastate discontinuances must rest on the possibility of permitting an interstate, but not an intrastate, discontinuance in these latter circumstances, we thus have further proof that both types of discontinuance are being subjected to the same standards.

Further indirect evidence of the Commission's determination to treat all discontinuances under a single set of substantive standards is found in the New Haven Discontinuance case, where the Commission, after including intrastate discontinuances within a $13 a(1)$ proceeding, subjected them to the same standards that it applied to the interstate discontinuances clearly before it. ${ }^{67}$ Finally, it is interesting to note that the only official discussion of the possible differences between the two types of discontinuance is found in a footnote to a Supreme Court decision in an intrastate discontinuance case. There the Court cites some highly equivocal legislative history as establishing the identity of the standards for the two types of discontinuance. ${ }^{68}$

Just as they appear to treat interstate and intrastate discontinuances alike, the cases exhibit a strong tendency to ignore the very extensive differences in language, approach, and legislative history, and to subject discontinuances and abandonments of branch lines to identical substantive standards. ${ }^{69}$ Indirect but compelling proof of this is to be found

65 New York, N.H. \& H.R.R. Discontinuance, 327 I.C.C. 151, 255 (1966); Atchison, T. \& S.F. Ry. Discontinuance, 312 I.C.C. 79 (1960); Chicago \& NW. Ry. Discontinuance, 307 I.C.C. 463 (1959); Minneapolis \& St. L. Ry. Discontinuance, 307 I.C.C. 79 (1959); Great No. Ry. Discontinuance, 307 I.C.C. 59 (1959).

66 St. Louis S.W. Ry. Discontinuance, 307 I.C.C. 639 (1959); St. Louis-S.F. Ry. Discontinuance, 307 I.C.C. 477 (1959); Southern Pac. Partial Discontinuance, 307 I.C.C. 209 (1959); Louisville \& N.R.R. Discontinuance, 307 I.C.C. 173 (1959).

67 New York, N.H. \& H.R.R. Discontinuance, 327 I.C.G. 151, 201, 206, 229 (1966).

68 Southern Ry. v. North Carolina, 376 U.S. 93, 103 n.16 (1964). The dissent persuasively draws the opposite conclusion-i.e., that Congress intended separate standards for interstate and intrastate discontinuances. $I d$. at 114-19.

69 One exception may be found in the treatment of labor. The ICC has held that 
in the degree to which section 13a cases are cited, without qualification or identification as such, as precedents for section 1(18) total abandonment cases, and vice versa. In fact, Southern Railway $v$. North Carolina, an intrastate discontinuance case and the only Supreme Court case interpreting the substantive provisions of $13 \mathrm{a}$, is cited as the controlling authority for every type of abandonment or discontinuance. ${ }^{70}$

\section{The Southern Railway Case}

As we have demonstrated with respect to procedural aspects, a single standard should apply to all types of service withdrawals. But it remains to determine the content of this standard. This task will require a close examination of the two most important decisions in this area: Southern Ry. v. North Carolina ${ }^{71}$ and New York, N.H. \& H. R.R. Discontinuance. ${ }^{2}$

The Southern Railway, after unsuccessfully requesting permission from the North Carolina Utility Commission to discontinue the last two passenger trains between Greensboro and Goldsboro, North Carolina, invoked ICC jurisdiction under section 13a(2)..$^{73}$ The ICC found

while the effect on labor is a factor to be considered in granting a discontinuance, the Commission cannot issue an order making the discontinuance conditional on the carrier's providing financial protection for employees. Great No. Ry. Discontinuance, 307 I.C.C. 59 (1959); compare the ICC's power to issue a conditional order under section 1(18), discussed in note 49 supra. The Commission's position is based on the fear that disparate results would otherwise occur, since states granting discontinuances might not give employees similar protection. On the basis of similar reasoning, the ICC has ruled that since it cannot impose conditions for the protection of labor on an interstate discontinuance under section 13a(1), neither can it impose such conditions with respect to an intrastate discontinuance.

Apparently, the prohibition on imposing conditions extends to all types of restrictions that might be imposed on a carrier as a condition for granting a discontinuance under section 13a. See Minneapolis, St. P. \& S.S.M.R.R. Discontinuance, 307 I.C.C. 125 (1959) (section 13a(1)); Missouri Pac. R.R. Discontinuance, 14 Fed. Carr. Cas. 40, 184 (1960) (section $13 a(2)$ ).

Although the Commission's interpretation of section 13a seems sound enough, there appears to be little justification for treating workers harmed by a discontinuance differently from those harmed by a total abandonment. The value to labor of being considered as part of the total picture affecting the final outcome of a discontinuance seems quite limited, and it is difficult to find a case where it has had any impact at all. Moreover, if a discontinuance were otherwise justified, it seems odd to force a carrier to continue operations just to protect jobs when by making appropriate financial provisions for the affected workers, all interests could be satisfied.

70 Tri-B Corp., Shelby, Iowa v. ICC, 253 F. Supp. 715, 718 (S.D. Iowa 1966); Humphreys v. United States, 228 F. Supp. 910, 913 (N.D. Cal. 1964); Northwestern Pac. R.R. v. United States, 228 F. Supp. 690, 696 (N.D. Cal. 1964); Chicago, R.I. \& Pac. R.R. Discontinuance, 328 I.C.C. $278,294-96$ (1966).

71376 U.S. 93 (1964).

72327 I.C.C. 151 (1966).

73 The Supreme Court of North Carolina upheld the Utility Commission's decision in State ex rel. Util. Comm'n v. Southern Ry., 254 N.C. 73, 118 S.E.2d 21 (1961). 
that the costs of providing these services were three times the revenues derived from them; that the railroad would save $\$ 90,589$ per annum by discontinuing the services; that the need for the services was insubstantial despite a fairly high population density in the area; that existing rail, bus, and airline services between the two cities were reasonably adequate; and that discontinuance would not seriously hamper industrial growth in the area. ${ }^{74}$ The Commission did not attempt to determine either the profitability of freight traffic over the affected lines, or the carrier's total earnings from traffic within North Carolina. It stated that it had considered but had given little weight to the carrier's overall prosperity. ${ }^{75}$

On the basis of these findings, the Commission determined that continued operation would constitute a wasteful service and would impose an undue burden on interstate commerce; it therefore authorized the carrier to discontinue. ${ }^{76}$ On appeal, a three judge district court found that the Commission had erred in not considering the carrier's overall earnings from both freight and passenger services on the segment of the line in issue; accordingly, the court perpetually enjoined the carrier from discontinuing the two passenger trains. ${ }^{77}$ The Supreme Court,

74 Southern Ry. Discontinuance, 317 I.C.C. 255 (1962).

75 The Commission had similarly interpreted section $13 \mathrm{a}(2)$ in Southern Pac. Partial Discontinuance, 312 I.C.C. 631 (1961), and in Chicago, M., St. P. \& Pac. R.R. Discontinuance, 307 I.C.C. 668 (1960). In the former case, the Commission held that the purpose of section 13a(2) was to permit the discontinuance of services that no longer pay their way and for which there is no longer sufficient public need to justify financial loss. The Commission stated that nowhere in the Act was there an indication that the prosperity of a carrier's interstate operations, or any segment thereof, is relevant to the determination of whether a given intrastate train imposes an unjust and undue burden on interstate commerce.

76 Southern Ry. Discontinuance, 317 I.C.C. 255, 260 (1962).

77 North Carolina v. United States, 210 F. Supp. 675 (M.D.N.C. 1962). The three judge decision was based largely on the failure of Congress to authorize the ICC in proceedings under section 13a to disregard the overall profits derived by a carrier from its operations within the affected state. This, according to the court, implies that the Commission might consider such intrastate operations as a significant factor in deciding intrastate discontinuance cases. The court pointed out that prior to the Transportation Act of 1958 the Supreme Court, in two cases, had required the ICC to weigh the effect of allegedly discriminatory rates on a carrier's intrastate operations as well as on its overall operations. Public Serv. Comm'n v. United States, 356 U.S. 421 (1958); Chicago, M., St. P. \& P. R.R. v. Illinois, 355 U.S. 300 (1958). It was only by means of an amendment to section 13(4) of the Act that the Commission was authorized to ignore the strictly intrastate effects of a given rate. 72 Stat. 570-71 (1958), 49 U.S.C. \$ 13(4) (1964). Therefore, the court concluded, since the effect of discriminatory intrastate rates is identical to the effect of the continued operation of money-losing intrastate service, in the absence of specific authority in section 13a to the contrary, the Commission is bound by the reasoning of the Supreme Court in the rate discrimination cases and must consider the overall return to the carripr 
with two Justices dissenting, reinstated the ICG authorization for discontinuance. ${ }^{78}$

According to the Court, the purpose of the Transportation Act was to permit the discontinuance of services that no longer paid their way and no longer met a public need sufficient to outweigh the heavy financial losses implicit in their continued operation. ${ }^{79}$ Furthermore, the Act cannot be read as requiring the Commission to consider the prosperity of all other segments of the carrier's intrastate operations as relevant to the problem of determining whether operation of a given intrastate train imposes an unjust and undue burden on interstate commerce. ${ }^{80}$ Generally, concluded the Court, the Commission should weigh the degree of public inconvenience that might result from a discontinuance against the carrier's ability to absorb continuing losses; but, if the Commission finds little public need for the service, it may justifiably give little weight to the size of the loss engendered by the disputed operations as compared to the carrier's overall prosperity. ${ }^{81}$

of all its operations within the state. The majority deemed irrelevant the substance and history of the rate discrimination legislation cited by the lower court. 376 U.S. at 98, 111.

78 Id. at 106.

79 Id. at 101. Here the Court quoted at length from the ICC opinion in Southern Pac. R.R. Partial Discontinuance, 312 I.C.C. 631, 633-34 (1961). See note 75 supra.

80 The Court stated: "But neither the profitability of such freight operations as are fortuitously conducted on the same line as a given passenger service nor the profitability of all operations within any given State bears any practical relationship either to the public's need for the service in question or to the burden which the deficit imposes on interstate commerce." 376 U.S. at 103 n.16. This argument would appear unanswerable with regard to "undue" burdens on interstate commerce. However, it does not directly deal with "unjust" burdens which apparently are assumed to add little or nothing to "undue" burdens.

81 The Court also rejected the argument that the Commission's decision ignored the legislative history of the Act and, in effect, read the phrase "unjust burden" out of section 13a(2). The statute, according to the dissent, conditions the granting of an intrastate discontinuance upon a demonstration that public convenience and necessity permit the discontinuance and that continued operation would constitute an undue and unjust burden on interstate commerce. Presumably, the "justness" and "dueness" of the burden on interstate commerce and on the carrier that might result from continued operations cannot be determined without an examination of both the carrier's earnings on the affected lines and its overall prosperity. Unless these factors are considered, every loss could be deemed undue and unjust. Such a standard, they argued, was explicitly rejected by Congress when it substituted the present language for that of the original Senate bill, which would have permitted both interstate and intrastate discontinuances solely on proof of a net loss in providing a given service. See note 56 supra. The dissent interpreted this history as proving that the net loss standard must not be applied, at least in intrastate discontinuances. 376 U.S. at 114-18.

It is difficult to take serious issue with that portion of the Southern Railway decision which found that the propriety of an intrastate discontinuance is totally unrelated to the profits the carrier earns over the line affected by the discontinuance, or within the state 


\section{The New Haven Case}

The New Haven case involved an interstate discontinuance under section $13 \mathrm{a}(\mathrm{I})$, although, as previously noted, the Commission included certain intrastate services within its decision and order. ${ }^{82}$ The railroad argued that discontinuance of all its passenger services was necessary for the protection of its freight services; and that according to the national transportation policy, the legislative history of section 13a, and prior Commission decisions, the protection of freight services should be carriers' and the Commission's first concern. The latter argument was supported with the Boston \& Maine Corp. Discontinuance cases, in which the Commission had accepted the proposition that the instant carrier's passenger services should be sacrificed to save its freight services. ${ }^{83}$

At the beginning of its discussion and conclusions, the Commission quoted the statutory language to show that in an interstate discontinuance case "continuance of all or part of the involved service may

in which the line is located. A railroad may earn large profits from its freight traffic over a given line. It also may earn a total profit from all operations within a state. But neither of these facts is relevant to the need for the service or to the effect on the carrier's financial stability or on interstate commerce of continuing it. The need for the service must be determined by analyzing the effects of withdrawing it, and the financial effect on the carrier of continuing the service can only be determined by examining its operations throughout its entire system. The weak point, if any, of the decision is its failure explicitly to expound the significance of "unjust burden," leaving the impression, as asserted by the dissent, that "unjust burden" has been equated with "undue burden." For a discussion of "undue burden" in an analogous context see Colorado v. United States, 271 U.S. 153 (1926); Wisconsin R.R. Comm'n v. Chicago, B. \& O. R.R., 257 U.S. 563 (1922).

However, in the absence of any legislative guidance regarding the significance of an "unjust burden" as compared to an "undue burden," the Court cannot be criticized for refusing to add blindly an additional concept to abandonment law. Moreover, a recent case has held that with respect to rate discriminations under section 13(4) of the Act, "undue burden" is synonymous with "unjust burden." Utah Citizens Rate Ass'n v. United States, 192 F. Supp. 12 (D. Utah), aff'd, 365 U.S. 649 (1961). See also note 61 supra.

82 See text at note 37 supra.

83324 I.C.C. 705, 723-25 (1965); 324 I.C.C. $418,452-55$ (1965). The two cases involved attempts by the Boston and Maine to discontinue its interstate and intrastate passenger service, respectively. The Commission, with a fascinating reverse twist, inserted this notion of balancing freight vs. passenger services into its consideration of public convenience and necessity. That is, rather than limiting the concept of public convenience and necessity to the needs of the patrons of the service to be discontinued, the Commission also considered the advantages that would flow from preserving the railroad whose existence was threatened by the continuance of that service. In the first cited case the Commission stated: "The elimination of that burden is required in the public interest, in order that the railroad itself might be preserved to provide essential services over the wide area of New England for the hundreds of communities therein which are greatly dependent upon it for their economic well-being and general welfare.

"The public convenience and necessity most assuredly permits, even requires, the discontinuance of the trains here in issue." 324 I.C.C. at 723. 
be required, for as much as a full year, only (emphasis in original) if the Commission finds: 'that the operation of such train or ferry is required by public convenience and necessity and will not unduly burden interstate or foreign commerce. . . " "84 Next the Commission stated that there were two tests to be applied-public convenience and necessity and undue burden-and proceeded to discuss the former solely in terms of patronage and the latter in terms of the financial burden on the carrier of providing the services. ${ }^{85}$ In this regard, the Commission found that many of the services involved were essential not only to the communities directly involved, but also many other communities within and beyond Southern New England; that the carrier was in terrible financial shape (it was under trusteeship); and that the carrier's passenger services contributed heavily, though not exclusively, to its financial difficulties. ${ }^{86}$

The Commission rebuffed, however, the carrier's attempt to deal with all passenger services as a single unit, and found "no justification" for the discontinuance of all the passenger services to save the freight services. ${ }^{87}$ In doing so, the Commission ruled that it was free to determine whether a carrier's freight or passenger services should be deemed of paramount importance. ${ }^{88}$ The Boston of Maine situation was distinguished on the grounds that there the carrier was primarily a freight carrier, whereas the New Haven's passenger services were as, if not more, important than its freight services. ${ }^{89}$ The concept of passenger or freight predominance does not fit easily within the statutory confines of sections $13 \mathrm{a}$ and $1(18)$, but the Commission made no effort to clarify this point in either decision.

The Commission also seemed to hint at an alternative argument; namely, that the New Haven's freight services were also losing money, and eliminating the passenger services would not by itself put the railroad in the black. ${ }^{30}$ The significance of this argument is somewhat obscure if we accept the thesis that it is the freight services that must be saved, since in that case any action that reduces the overall deficit contributes to the desired end. The propriety and utility of a regulatory scheme that forces the Commission to make excruciating choices between freight and passenger services in situations in which both are

84327 I.C.C. at 202.

85 Id. at 202-16.

86 Id. at 202-03.

87 Id. at 204.

88 Id. at 154-55.

89 Id. at 203-04.

90 Id. at 203. 
essential is one of the main concerns of this article, and it will be discussed in detail shortly. ${ }^{91}$

Having refused to treat the passenger services as a unit, the Commission ordered the New Haven to continue all of its commuter services and some of its through services. ${ }^{92}$ According to the Commission, the intent of the statute was that carriers should be required to continue those train services which "are essential to meet the demonstrated needs of the public and which appear to have sufficient potential for being economically viable." 93 Apparently, these included all existing commuter services. The Commission made no specific findings as to the burdens imposed by continuing individual trains and runs, although at various points it indicated disagreement with the railroad's estimates on these matters. ${ }^{94}$

Without impugning the excellent motives of the Commission, and without underestimating the tremendous handicaps imposed upon it by the vagueness of the statute and the weakness of the entire regulatory scheme, it may be said that the Commission quite clearly did not believe its own findings and was in fact granting temporary relief by improvising on the statute. The order to continue service was made effective only for eight months, rather than for the statutory maximum of twelve months. This was done, according to the Commission, both to give the New Haven the opportunity and flexibility to work toward establishing an operating framework of "essential" passenger service, a goal that the instant proceeding seemingly could not achieve, and to freeze matters until the outcome of the proposed Pennsylvania and New York Central merger was determined, since purchase of the New Haven had been made a condition of the Commission's approval of the merger ${ }^{95}$ Moreover, the railroad was to be given time to try to improve its efficiency and to make its passenger services more attractive and profitable, and the affected communities were to be given time to offer various types of assistance to the railroad. This implied that many of the services involved did indeed meet the requirements for discontinuance; but that the issues were so important and complicated that, rather than for the Commission to issue a final order, the interested parties should be given more time to work out their own solution. Unquestionably, this was the best solution to the New Haven problem. But section 13a makes no provision for such an interlocutory order; in fact, the entire

91 See discussion at notes 103-04 infra.

92327 I.C.C. at 205-18.

$93 \mathrm{Id}$. at 205.

$94 I d$. at 188-99, 203, 206.

$95 I d$. at 216-18. 
thrust of the statute is to facilitate interstate discontinuances by severely limiting the Commission's power to delay such actions. ${ }^{96}$ In any case, we shall return to this interesting procedural innovation at a later point.

\section{How Abandonment Decisions Are Made}

Even the most careful reading of court and Commission decisions in discontinuance and total abandonment cases does not yield a particularly clear picture of the decision-making process applied in these cases. And the contrast between the dual standards of public convenience and necessity and undue burden on interstate commerce for discontinuances under section 13a, and the single standard of public convenience and necessity for total abandonments under section 1(18), hardly makes for clarity. Some pattern may be discerned, however, if we assume that in all cases the Commission weighs the relative impacts on all interested parties of continuing or withdrawing the services at issue, and that the seemingly divergent criteria provided by sections $1(18)$ and $13 a$ are actually only different ways of denominating the same range of interests and effects.

For total abandonments, the single concept of public convenience and necessity must include all effects on all interested parties of continuing or withdrawing the services at issue. We may conveniently divide the interested parties into three groups: users of the services at issue; users of the carrier's other (passenger or freight) services; and various outsiders, such as storekeepers in communities dependent upon factories that ship over affected lines, and citizens of nearby metropolises that might suffer from increased strain on their street, parking, and public transportation facilities if rail passengers were forced to commute by road. Withdrawing existing services affects the first group and some members of the third; continuing those services affects the second group and some of the members of the third, the latter not necessarily being different from those who are affected by withdrawing the services. The impact of withdrawing existing services is straightforward enough. The impact of continuing those services is somewhat more complicated: continuation at a loss may force users of the carrier's other services to pay what amounts to a subsidy; and may, insofar as it reduces the viability of the carrier, threaten both the other services' users and the miscellaneous parties with a total collapse of all services.

For discontinuances under section 13a, the two concepts of public

96 For interstate discontinuances, the Commission must order an investigation within thirty days or permanently lose all jurisdiction over the matter. Sludden v. United States, 211 F. Supp. 150 (M.D. Pa. 1962). Thereafter the Commission has but four months to make its investigation and render a decision. See note 16 supra. 
convenience and necessity and undue burden on interstate commerce together encompass the same territory as does public convenience and necessity simpliciter under section 1(18). Indeed, as interpreted by the Commission, the two concepts of section 13a epitomize the classic duality of section $1(18)$ public convenience and necessity: public convenience refers to the effect of withdrawing the services at issue on their users and on other interested parties, and undue burden refers to the effect of continuing the services on all interested parties, including the services' users. But it should be noted that determining undue burden under section $13 \mathrm{a}$ is a multiple-step process. First, the effect of continuance of deficit-producing service is translated into its impact upon the carrier's ability to provide its other services at the going prices or, more likely, at any prices at all. Then, the effect of withdrawal of those other services is evaluated. Finally, the likelihood and effect of withdrawal of the other services are balanced against the direct effect of withdrawal of only the specific services at issue. ${ }^{97}$

After establishing all the factors relevant to each of the section 13a concepts, the Commission proceeds to weigh one set against the other. It does not reach conclusions with regard to each concept separately and then make a final decision. Rather, it looks to the magnitude of the impact on each interested group, and then to the relative importance of those groups. As we have seen, however, carriers are never required to continue deficit-producing services unless some substantial need for them is demonstrated (that is, unless there is a $P_{1} U_{1}$ or $P_{1} U_{0}$ situation). Finally, the effect of a given loss on an ultimate decision will vary in accordance with both the overall financial strength of the carrier and the importance of the services at issue. ${ }^{98}$

97 It appears that in the Boston 4 Maine case, the Commission departed from its usual practice by considering the ultimate consequences of continued operations in its treatment of public convenience and necessity in a section 13a discontinuance. Boston \& Maine Corp. Discontinuance, 324 I.C.C. 705, 723 (1965). Thus, the Commission stated that public convenience and necessity required the abandonment in order to preserve other, more important services of the carrier. Although this treatment can be defended if used consistently, it is out of step with the usual formulations in which such considerations are deemed relevant to undue burdens on interstate commerce; public convenience and necessity serves better if limited to the immediate impact of withdrawing a given service.

98 Thus the fate of a service of intermediate importance will depend in part upon the size of the loss compared to the ability of the carrier to bear it. As the importance of the service increases, the Commission will impose a larger relative loss on the carrier. Often there is a point at which a choice must be made between all passenger and all freight services. In the Boston Maine case the Commission decided that despite the possible serious consequences on the users and the surrounding community of withdrawing all passenger service, the carrier's freight services were more important to the area and could be preserved only by sacrificing the passenger service. By contrast, in New Haven, the Com- 


\section{Duties of the Carriers and the Communities}

Before we leave the cases, we should examine a heretofore unmentioned aspect of the Commission's decision in the New Haven case. Two particularly vexing aspects of passenger service problems are the level of effort carriers should make to attract profitable passenger business, and the degree to which the interested communities should assist carriers in preserving given services. Prior to New Haven, the Commission had declared that it would not find burdens on interstate commerce to be "undue" within the meaning of section 13a if the carrier had deliberately disregarded its services in order to prepare a case for discontinuance. ${ }^{99}$ In New Haven it ruled that a carrier must:

accord the promotion of its economically viable passenger service the same reasonable effort it would accord to promotion of its basic freight services, as for example, when the latter were threatened by competitive forces. This reasonable effort should be manifested by service improvements, longrange market analysis, rate reformation, capital investment in research and technological achievements applicable to passenger operations, and sound analysis of the real costs of providing passenger services with a rail plant used also for the provision of freight services. But it need not be sustained beyond that point at which the carrier can demonstrate an unwillingness on the part of the public either to sustain the services through patronage or by assuming a fair share of the cost of maintaining such services. ${ }^{100}$

The Commission continued, however, by declaring that the public must match the "reasonable effort" of the railroads by providing an appropriate level of support for these services:

[This] should not be interpreted as requiring a willingness by the public to "pay the bill" as tendered by the carrier or carriers providing such services at a deficit. Yet, it must imply something more than a mere willingness to provide only that financial assistance which is necessary to sustain such services, and possibly the financial condition of the carrier offering them, at a point just short of collapse. ... The reasonable level

mission deemed the passenger service such an important component of the carrier's functions that it refused to sacrifice it for the benefit of the freight service, and it was willing to accept greater damage to the carriers finances, at least in the short run. See text at notes 65 and 73-83, supra. See also Chicago, Rock Island \& Pac. R.R. Discontinuance, 328 I.C.C. 278, 294-96 (1966), for a particularly lucid exposition of this process.

90 Southern Pac. Co. Discontinuance, F.D. 23800 (Jan. 24, 1966).

100327 I.C.C. at 221 (emphasis in original). 
of public support should in fact be construed as that level of financial or other public assistance which will stimulate the carrier to initiate or, if already initiated, continue its own reasonable effort to sustain and improve essential and economically viable passenger services. ${ }^{101}$

According to the Commission, programs of public support should not be limited to financial help, but should include joint governmentcarrier efforts to determine future demands and requirements. ${ }^{102} \mathrm{But}$ the Commission declared itself unavailable to serve as an arbitrator to resolve "insoluble differences" arising during negotiations. ${ }^{103}$

These efforts at providing guidelines for carrier and public conduct regarding passenger service both represent a very interesting new departure for the Commission, and provide material for speculation and analysis. The need for, and the possible success of, this kind of approach will be discussed shortly in connection with proposals for alternate regulatory arrangements. It may be noted here, however, that the Commission's reference to the level of carrier and public support for "economically viable" services is puzzling: if subsidies are needed, the services are by definition not "economically viable." Perhaps the standard is economic viability without more subsidies than public authorities can reasonably be expected to provide, but the usefulness of this conceptualization is debatable.

\section{The Adequacy of the Existing Regulatory System; SOME Likely Alternatives}

Undoubtedly, regulation of discontinuances by the ICC within the substantive framework of public conveniences and necessity is preferable to exclusive state jurisdiction over discontinuances, or to regulation by the Commission in accordance with standards markedly different from those applied to total abandonments. But even granting this, the existing regulatory system is inequitable and ineffective; and it fails miserably when confronted with proposed discontinuances of important passenger services rendered by financially weak carriers such as the New Haven, the Boston \& Maine, and even the New York Central. Why should the Commission be faced with the necessity of choosing between passenger and freight services when both are often so vital to so many people?

The problem can be traced back to the absence of a national trans-

101 Id. at 222-23 (emphasis in original).

102 Ibid.

$103 I d$. at 219. 
portation plan, and to the inadequacy of the remedies currently available to the ICC. The solution lies in the formulation of a national transportation plan, and in a restructuring of the roles of the various agencies and political entities that deal with transportation matters. Hopefully, the newly created Department of Transportation will initiate the steps necessary to the former. ${ }^{104}$ But, whatever the possibilities of an overall structuring of our transportation needs and priorities may be, significant changes in the existing railroad regulatory system are essential to any satisfactory solution of our transportation problems. ${ }^{105}$ Therefore, the remainder of this article examines the structural weaknesses of the existing system, and presents some suggestions for reform.

\section{Deficiencies of the ICC's Existing Remedies}

Under circumstances in which the costs of given services cannot be recovered from the users thereof, current law affords the ICC two alternatives-continuance or abandonment. If abandonment is ordered, the impact will be borne by the former users of the services and by other groups affected either by the deprivation of the services or by the resulting switch to other forms of transportation. If continuance is ordered, the impact may be borne by one or more of several groups, none of whom have much interest in the preservation of the services. The railroad itself may assume the resulting losses, in which case the burden will be shifted to the railroad's shareholders and possibly (if a total collapse of services threatens) to other groups. Or, if the elasticity of demand and the ICC permit, the carrier may be able to adjust its other rates sufficiently to cover the losses, in which case the

104 Unfortunately, the role of the Transportation Department in national planning was limited to the establishment of criteria for federal investment in transportation. 80 Stat. 941 (1966) 49 U.S.C.A. \& 1656 (Supp. 1966). However, the formulation of such standards must be based upon determinations of the requirements for each type of transportation facility in each part of the country. If thoroughly done, this could form a solid basis for a true national transportation policy.

105 There have been numerous recommendations for improving the rail passenger service situation. See LockLIN, Economics of Transportation (5th ed. 1960). The Commission also made its own investigation and reported its findings in Railroad Passenger Train Deficit, 306 I.C.C. 417 (1959). Its recommendations included repeal of the federal excise tax on fares; amendment of the federal tax laws to encourage increased state and local tax relief consistent with the desire of these communities to retain commuter services; the takeover, in effect, of certain commuter services by local political bodies which would hire the carriers to operate them; and reconsideration by the Executive Branch of practices by the Post Office and Defense Departments in light of national transportation policy. Some action has been taken regarding local relief and operation of certain commuter services by the metropolitan communities served thereby. See note 110 infra. Of course, this type of action is not the particular concern of this article, which is directed towards structural problems. 
burden will be shifted to other passengers and shippers and ultimately to the consumers of the products shipped. ${ }^{106}$

Such results are at once inequitable and ineffective. A railroad's ability to continue providing money-losing services is limited by either its ability to pass the losses on to its other customers by charging higher rates, or by its ability to absorb the losses itself by digging into profits or assets. Similarly, fare increases can be accomplished only to the extent permitted by the appropriate regulatory agency and the elasticity of demand for the services concerned.107 Thus, the ability of the ICC to force subsidization of particular money-losing services is limited by factors irrelevant to the importance of those services. Services of equal importance, for example, may be continued or withdrawn depending on whether the carrier involved is a strong, mainly freight-carrying one such as the Sante $\mathrm{Fe}$, or a weak, mainly passengercarrying one such as the New Haven. Such results unjustifiably discriminate among citizens served by different railroads located in different parts of the country.

\section{Characteristics of an Ideal System}

What would be an ideal system? We have seen that the core of the railroad problem is the fact that the overall value of railroad services to the public often is greater than the amount users are willing to pay for those services. We have also seen that putting the losses engendered by money-losing services on carriers' shareholders and freight-service users is both ineffective and inequitable. ${ }^{108}$ Therefore, the situation seems to require some means by which the public can help to support rail services-or, to use a nasty phrase, subsidies financed by public revenues.

There is little difficulty in establishing the general principle that public subsidies of rail passenger services may often be appropriate; indeed, this seems to be widely accepted. Nor is there much difficulty in envisioning forms such subsidies might take; direct monetary payments, tax reductions, and low interest loans are among numerous examples. Devising a scheme for allocating the burden of providing subsidies presents, however, a real problem. A theoretical solution is easy to devise: each political entity involved should contribute an amount proportional to its interest in maintaining the services at issue.

106 S. ReP. No. 1647, 85th Cong., 2d Sess. 10-11 (1958). H.R. REP. No. 1922, 85th Cong., 2d Sess. 8-11 (1958). Fainsod, Gordon \& Palamountain, Government and the American ECONOMY 273-79, 283-85, 316 (3d ed. 1959).

107 Fainsod, Gordon \& Palamountain, op. cit. supra note 106, at 284-85, 310, 312. 108 See discussion and references cited in notes 56 \& 81 supra. 
But just stating this solution reveals its difficulties. One is inevitably reminded of the maneuvering, bargaining and name-calling that went on during the effort to obtain financial support for the New Haven from the various interested parties - the federal government; the states of New York, Connecticut, Rhode Island, and Massachusetts; the cities of New York, New Haven, Providence, and Boston, etc. ${ }^{109}$

\section{Subsidies Under the Existing System}

Of course, even now there exist both federal and state programs of railroad assistance. ${ }^{110}$ But the existing system provides no mechanism for harnessing the expertise and independence of the ICG to the financial resources of the assistance-granting agencies. The only options available to the ICG are to permit or to deny abandonment. Government bodies that might consider affording financial assistance in certain potential withdrawal situations often either fail to recognize a problem until withdrawal has become unavoidable, or; if they be-

100 See, e.g., N.Y. Times, Dec. 4, 1965, p. 38, col. 3; N.Y. Times, Dec 7, 1965, p. 39, col. 3. 110 Federal assistance is available under chapters 19 and 21 of the Interstate Commerce Act. 72 Stat. 568 (1958), 49 U.S.C. $\$ \$ 1231-40$ (1964); 78 Stat. 302 (1964), 80 Stat. 715 (1966), 49 U.S.C.A. $\$ \$ 1601-11$ (Supp. 1966). Chapter 19 makes federal guarantees available for loans to railroads for capital improvement or maintenance. Chapter 21 provides grants and loans to state and local public bodies for financing the acquisition, construction, and improvement of mass transportation services; for studies, development, and demonstration projects related to improved urban transportation; and for relocation payments to persons affected by mass transportation projects. Recently the federal government made a grant under Section 6 of the Mass Transportation Act, 78 Stat. 305 (1964), 49 U.S.C. $\S \S 1601-11$ (1964), to help develop high speed rail transportation between Boston and Washington, D.C.

The states provide a wide variety of assistance programs. Fainsod, GoRoon \& PALAMounTAIN, op. cit. supra note 106, at 315 . The northeastern states and municipalities have been most active in this regard. New York, Connecticut and New Jersey have entered into a compact to create a Regional Transportation Commission. New York has reduced certain taxes on railroads and has created a New York City Metropolitan Community Transportation Authority with broad power to assist, operate, regulate, and acquire railroad service. NEW YORK SESS. LAwS 1965, ch. 324. New Jersey has provided tax relief to passenger facilities, N.J. LAws 1948, ch. 40, has undertaken a study of its tax structure regarding railroads, Res. 12, 1963 Session, and has created a Transportation Department to control state policy regarding commuter railroads. N.Y. Times, June 14, 1966, p. 94, col. 6. Connecticut has authorized municipalities to provide for local railroad passenger stations, CoNN. GEN. STAT. ANN. § 16-139 (1960), and has granted certain tax exemptions to railroads, CoNN. GEN. STAT. ANN. § 16-75 (1960). Vermont has authorized the takeover and operation of the Rutland Railroad after abandonment was ordered by the ICC, Vt. Laws 1963, Public Act 162 , and New Hampshire has authorized municipalities to take certain actions to preserve threatened rail services. N.H. REv. STAT. ANN. 31.4 (1965).

Some states, though, seem to take a different tack. The North Dakota legislature passed a resolution in 1964 urging that the ICC forestall certain threatened abandonments, and in 1965 the Montana legislature passed a resolution opposing state ownership or "socialization" of the railroads. House Joint Res. No. 26, in MoNr. Laws 1965. 
come concerned at an appropriately early point, lack the technical competence or political fortitude to resolve the conflicting claims of the public and private parties concerned.

In the New Haven case the Commission attempted to improve upon existing law in this area by introducing two innovations. One was the establishment of guidelines for the level of assistance to be provided by the interested political bodies to supplement the carrier's efforts.111 Although the Commission should be commended for trying to hack a new path through the thicket and for striking out in the right direction, these guidelines and the type of approach they imply have a fatal flaw: like the substantive standard of sections $1(18)$ and 13a of the Act, they presuppose a case-by-case development of the specific contents of deliberately vague general standards. An obvious difficulty of such an approach is that at best a long period will be required to develop precise, workable standards. A much more serious difficulty is, however, that given the enormous variety of economic and social considerations arising in service withdrawal cases, there is little likelihood of even the eventual development of standards that will permit the interested parties to determine their mutual obligations prior to litigation of the proposed withdrawal before the Commission. Once litigation has begun, of course, any corrective action is too late, unless there are provisions for a series of attempts to divine the appropriate levels of assistance and carrier effort.

The Commission's second innovation in the New Haven case was its transformation of the customary final decree into an interim order operating for only eight months, an adjustment that was explicitly designed to give the parties an opportunity to review the entire situation before any final action was taken. ${ }^{112}$ This type of action does not appear to be authorized by the statute. Conceivably, the New Haven case itself could be defended as a one-shot affair relating to the Commission's declaration of new standards for carrier effort and community subsidy. But this would be misleading, for the Commission's standards are so imprecise that even forewarned and well intentioned litigants probably will not be able fully to comply with them. Nevertheless, the use of interim opinions, coupled with the determination of precise standards for carrier effort and community assistance, might form the basis for one type of workable alternative to the existing system.

One of the most interesting and, perhaps, saddening aspects of the current rail regulatory picture is the struggle of the Commission to

111 See text at notes 101-104 supra.

112 New York, N.H. \& H.R.R. Discontinuance, 327 I.C.C. 151, 216 (1966). See also discussion at notes 95-96 supra. 
manipulate the existing system to accommodate the concepts and procedures suggested in this article. Unfortunately, the manipulability of the existing system is limited; and, to the extent the Commission refrains from providing specific guidance to interested parties regarding their mutual responsibilities in a withdrawal situation, the end of maximum mobilization of community resources in support of desired and important rail services is not achieved.

\section{The Procedural Requirements for Effective Use of Subsidies}

If public subsidies are indeed the most equitable and effective means of preserving certain types of rail passenger services, we must alter our existing procedures to permit effective use of this type of remedy. Adequate procedures for this purpose would have two features: they would provide a method for determining the duties of the carrier and the responsibilities of the subsidy-granting agencies, and they would make this information known to all interested parties in sufficient time for the latter to make use of it. The Commission in the New Haven case tried to graft these features onto the existing system. Its efforts fell short, however, due to conflict with the existing statutes and to lack of a method for determining the various parties' duties and responsibilities prior to final adjudication.

Nevertheless, adequate procedures could be devised without doing untoward violence to existing institutions and methods of political operation. Central to any adequate procedural system would be the institution of a preliminary fact-finding hearing as a prerequisite to any rail service withdrawal. The power to invoke this hearing would be vested in carriers seeking withdrawal, the Commission itself, and all other parties having a strong interest in the maintenance or withdrawal of particular services. The purpose of the hearing would be to ascertain all of the facts relevant to the future of the services at issue-the financial results of current operations; the existing and potential demand for the services; the likely impact on the carrier, the users of the services, and other relevant groups of maintaining or withdrawing the services; the sufficiency of the carrier's efforts to make the services economically viable; and the amount and apportionment of financial support, if any, that would have to be forthcoming from interested parties if the services were to be maintained. Parties represented at the hearing would include the carrier, the users of the services, states, municipalities, and the federal government. The share to be provided by the federal government would be determined in accordance with the national interest in maintaining the services, and to this end the Com- 
mission would be empowered to make the carrier eligible for specified types of federal assistance. After the Commission's findings were promulgated, the carrier, states, and municipalities would be given time to take the recommended steps.

Later, any party dissatisfied with the performance of any other party would be empowered to invoke a second proceeding. At this proceeding the ICC would determine the extent of compliance with its guidelines. If the Commission were to find that its recommendations had been substantially followed, it would probably order continuance of the services for a specified period. If it were to find that its recommendations had not been followed, it would be able to utilize a wide range of remedies. These would include the powers to increase the level of federal support; order the carrier to assume a somewhat greater (though statutorily limited) share of the costs of continuing the service; and to order continuance of services pertaining to groups willing to undertake their share of the costs, while permitting withdrawal of services pertaining to groups not so willing. Conceivably, the Commission might be able to persuade some of the parties to increase their contributions to cover the defaults of others. Finally, it might, if it were convinced that it had no reasonable alternative, permit withdrawal of some or all of the services at issue. A decision ordering continuance or permitting withdrawal would be appealable in the same manner as any other final order.

\section{Pros and Cons of the Proposed System}

One purpose of this proposed system would be to create within the concepts and traditions of our existing institutions a regulatory system imposing the responsibility of supporting rail services on the parties most affected by them and most capable of providing support. Another would be to give the ICG procedural and substantive tools that are sufficiently flexible to cope with the complexity and diversity of the situations arising in this area. The existing system fulfills neither of these two purposes: the Commission has only the single remedy of requiring the carrier to support the services, and it must make its decision to grant or withhold this remedy after only a single, all or nothing, adjudicatory hearing. Moreover, although interested political units can and do under the existing system subsidize particular rail services, the difficulties of coordinating political remedies with the regulatory process are almost insurmountable.

The proposed system would not avoid, however, the disadvantage that funds to maintain rail services would still have to be obtained 
from states and municipalities. The possibility that some political units affected by the services at issue might not provide sufficient support would create great difficulties for the Commission. Under ideal conditions it might be possible to discontinue services to nonsupporting political units while at the same time maintaining services to those willing to bear their fair share of the burden, or to make up the difference with federal funds. Alternatively, the supporting political units might be persuaded to increase their ante.

Furthermore, upon first view it might appear that the proposed system would impose great additional burdens upon the Commission. Not only would the Commission have to determine the level of support necessary to maintain the services at issue; it would also have to allocate responsibilities among the parties involved, and, to the extent that any of those parties were not to accept their responsibilities, make further adjustments in the overall scheme. But complexities of this sort stem from the nature of the problems, and not from the system proposed to deal with them. Is it not far better to have these decisions made by an organization with the expertise, experience, and impartiality of the ICC, than to have them go unmade, or to have them made through a hit or miss process of haggling among carriers, users, political units, and regulatory agencies? Besides, under the existing system the Commission actually makes much the same type of findings it would make under the proposed system; the only difference is that, instead of having multiple remedies and a flexible procedure to implement them, the Commission must make agonizing choices-continuance versus withdrawal, passengers versus freight, commuters versus employees of industries located along unprofitable rail lines-of the sort that confronted and confounded it in the New Haven and Boston \& Maine cases.

\section{An Alternative}

An alternative to the system proposed above would be one in which the ICC itself would provide subsidies to maintain rail passenger services deemed to be of unusual public interest. Such a system would avoid one disadvantage to the first system; namely, that funds to maintain rail services would have to be obtained from states and municipalities. But against this gain would be the loss of the principle that those benefiting from given services should pay a substantial portion of the cost of maintaining those services. This suggests that the alternative system should be rejected unless it can be demonstrated conclusively that a combined federal-state-municipal system simply would not work. 


\section{CONCLUSION}

If successful, this article has done three things. First, it has demonstrated that, regardless of what the statute appears to say, there is but a single method of deciding all types of rail service withdrawal cases. The heart of this method is a rather complex balancing test looking to the impacts on all affected parties of either continuing or withdrawing the services at issue. Second, this article has shown that the notion that the appropriate parties to subsidize money-losing passenger services are carriers and freight shippers is inequitable and self-defeating. A more equitable and effective approach would be to impose this burden on the states and municipalities benefiting from such services. Third, this article has presented an outline for revising the existing system to permit more effective use of the Commission's abilities to analyze rail situations, and of states' and municipalities' abilities to provide supporting funds. Under this outline the Commission's first act in any rail service withdrawal situation would be to hold a fact-finding proceeding for the purposes of determining the level of support necessary to maintain the services at issue, and of allocating responsibilities among the parties involved.

Admittedly, this article has not presented a specific proposal for an alternate system. Before legislation could be enacted, a host of ancillary questions would have to be answered: should time limits be imposed on the various stages of the proposed procedure; and, if so, what should they be? What kind of federal assistance should be available, and how should the amounts be determined? To what extent should carriers be obliged to support passenger services with freight revenues? Questions of this sort could, however, be easily answered as soon as there was general agreement with the propositions presented in this article. 